\title{
Benign Approaches for the Microwave-assisted Synthesis of Quinoxalines
}

\author{
Farshid Mohsenzadeh, Kioumars Aghapoor and Hossein R. Darabi* \\ Chemistry \& Chemical Engineering Research Center of Iran, P. O. Box 14335-186, Tehran, Iran
}

\begin{abstract}
Neste trabalho foram usados dois sistemas simples, rápidos (3 min) e versáteis, de transferência de energia de microondas, na ausência de solventes, para a síntese de quinoxalinas (2,3-difenilquinoxalina e seus derivados, 2,3-difenil-4a,5,6,7,8,8a-hexahidroquinoxalina, 2fenilquinoxalina, piridina-2,3-diamina e 2,3-dihidro-5,6-difenilpirazina). O primeiro método consiste no uso de suportes minerais na reação de 1,2-dicarbonil (benzil) ou $\alpha$-hidroxicetona (aciloína) com 1,2-diaminas. Entre os suportes minerais, a eficiência da alumina ácida como catalisador foi claramente comprovada (80-86\%). Além disso, apresenta um papel importante na oxidação de aciloína ao correspondente sistema 1,2-dicarbonílico. O segundo método consiste no uso de microondas em mistura dos reagentes 1,2-dicarbonil(benzil) e 1,2diaminas. O excelente rendimento dos produtos (90-97\%) e a simples lavagem com água e filtração na ausência de solventes orgânicos fazem desse sistema uma ótima alternativa para a prevenção de poluição, em um processo ambientalmente benigno. Embora os dois métodos tenham sido planejados para evitar passos adicionais de purificação, o último é um processo mais limpo com tratamento reacional mais simples.
\end{abstract}

Two benign, simple, rapid ( $3 \mathrm{~min}$ ), solvent-free and versatile microwave energy transfer systems for the synthesis of quinoxalines, i.e. 2,3-diphenylquinoxaline and its derivatives, 2,3diphenyl-4a,5,6,7,8,8a-hexahydroquinoxaline, and 2-phenylquinoxaline and also pyridine-2,3diamine and 2,3-dihydro-5,6-diphenylpyrazine have been used. The first approach consists on the use of mineral supports on the reaction of 1,2-dicarbonyl (benzil) or $\alpha$-hydroxyketone (acyloin) with 1,2-diamines. Among mineral supports, the efficiency of acidic alumina as catalyst was clearly proved (80-86\%). Moreover, it has an oxidative role in the tandem oxidation of acyloin to the corresponding 1,2-dicarbonyl. The second approach is the use of polar paste system on the reaction of 1,2-dicarbonyl (benzil) with 1,2-diamines. The excellent products yield (90-97\%) and simple washing with water and filtration in the absence of organic solvent makes it an impressive alternative green platform. Although both methods implemented in this study have been designed to circumvent additional purification steps, the latter is cleaner with an easier work-up.

Keywords: microwave, quinoxalines, polar paste, acidic alumina

\section{Introduction}

Quinoxaline derivatives are the subject of considerable interest from both academic and industrial perspective. Among the various classes of nitrogen containing heterocyclic compounds, quinoxalines are important components of several pharmacologically active compounds. ${ }^{1}$ Although rarely described in nature, synthetic quinoxaline ring is a part of a number of antibiotics which are known to inhibit the growth of Grampositive bacteria and are also active against various transplantable tumors. ${ }^{2}$

*e-mail: darabi@ccerci.ac.ir; r_darabi@yahoo.com
From the synthesis standpoint, despite remarkable efforts in the last decade, ${ }^{3-7}$ the development of effective methods for the synthesis of quinoxaline is still an important challenge. By far, the most common method relies on the condensation of an aryl 1,2-diamine with a 1,2-dicarbonyl compound in refluxing ethanol or acetic acid for 2-12 h. For example, the condensation of 1,2diaminobenzene with benzil provides quinoxaline 1a in literature yields ranging from $34-85 \%$ depending on the reaction conditions. ${ }^{8}$ In a particular case, iodinecatalyzed reaction gives high yields of the products at room temperature while the method suffers from environmental problems due to iodine and solvents toxicity. ${ }^{9,10}$ 
It is nowadays of prime interest to connect research in chemistry and environmental protection. So a number of procedures is now recommended for Green Chemistry ${ }^{11,12}$ involving: either new eco-friendly reagents and catalysts, selected medium such as water, supercritical fluids, ionic liquids or solvent-free reactions, non-classical modes of activation such as ultrasounds or microwaves.

When Solvent-free methods coupled to microwave irradiation (MWI), it results in very efficient and clean procedures with noticeable improvements over classical methods. Unlike traditional thermal heating, microwaveassisted synthesis of quinoxalines is carried out in very short period of time. ${ }^{13-16}$ However, the reported procedures suffer from drawbacks such as the requirement of strong organic acid as catalyst, ${ }^{13,14}$ and high volume of solvent. ${ }^{15}$ In the best example, designed microwave equipment with extremely harsh reaction conditions $\left(5 \mathrm{~min} / 160^{\circ} \mathrm{C} / \mathrm{HOAc}\right.$ condition) was reported. ${ }^{16}$

In embracing the principles of green chemistry and considering the recent progresses in rapid synthesis methodologies such as microwave method, ${ }^{17}$ the important role of solvent-free conditions coupled with microwave activation $^{18}$ and our experience in the use of microwave heating in organic reactions, ${ }^{19}$ herein we report two general new approaches to the synthesis of quinoxalines $\mathbf{1},(i)$ the use of mineral supports under solvent-free conditions, and (ii) the application of an alternative polar paste system.
The absence of strong and corrosive acids, the absence of solvents, high yields and the overall low waste generation of these approaches give them attractive green chemistry metrics, along with remarkable versatility.

\section{Microwave-assisted synthesis of quinoxalines}

Microwave-assisted organic synthesis has had a profound impact on the way chemists approach organic and parallel synthesis. Clearly, reductions in reaction times, improved yields and suppression of side products, relative to traditional thermal heating, are benefits of this emerging technology. ${ }^{20}$

Herein, two benign, simple and versatile routes to quinoxalines 1 in high yields have been demonstrated. The study investigates the synthesis and characterization of products 1a-h by the use of mineral supports under solventfree conditions, and also the use of a polar paste system.

The microwave-assisted condensation was carried out between $\alpha$-dicarbonyls such as benzil ( $\mathrm{PhCOCOPh)}$ and phenylglyoxal monohydrate (PhCOCHO) and also acyloin with various diamines such as benzene-1,2-diamine, 4-methylbenzene-1,2-diamine, 4,5-dimethylbenzene-1,2diamine, 4-nitrobenzene-1,2-diamine, cyclohexane-1,2diamine, ethylene-1,2-diamine and pyridine-2,3-diamine. The structures of ten substrates and eight products are shown in Scheme 1.

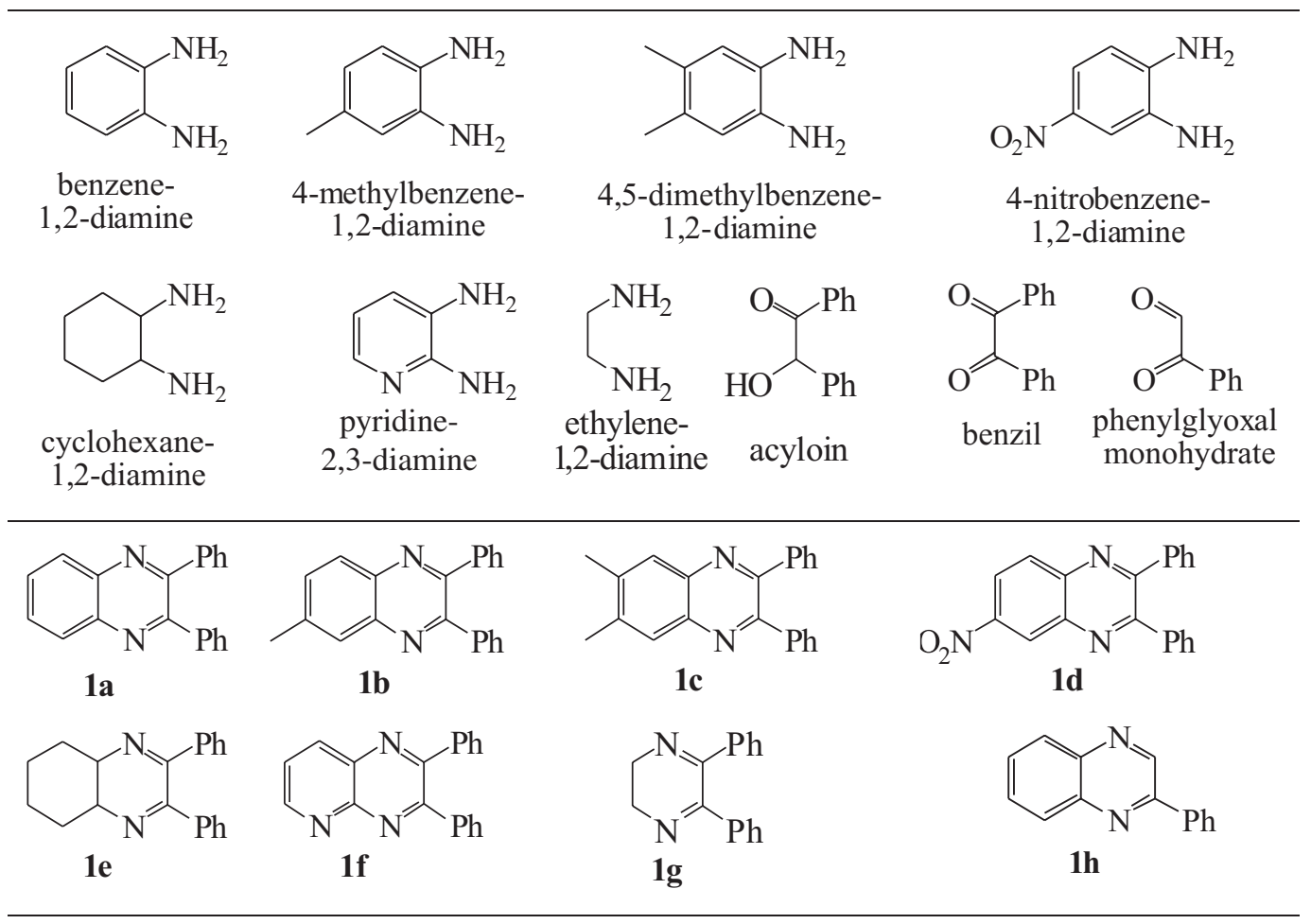

Scheme 1. 


\section{Application of inorganic solid supports}

The initial laboratory-scale feasibility of microwave promoted solvent-free procedures has now been illustrated for a wide variety of useful chemical reactions on mineral supports. ${ }^{21}$ The use of environmentally friendly inorganic solid supports such as aluminas, silica gels and montmorillonites as catalysts or reaction media, is rapidly increasing because these reactions, compared to their homogeneous counterparts, often involve milder experimental conditions, an easier set-up and work-up, more rapid reaction rates, increased yield, easy removal, recycling and reuse of catalysts, and minimal wastes. ${ }^{22}$

Our general procedure involves simple mixing of neat reactants with the catalyst, their absorption on mineral and exposing the reaction mixture to irradiation in a commercial microwave oven. Preliminary optimization of reaction conditions was performed using 1,2diaminobenzene and benzil in a solvent-free condition (Table 1, Entry 8). In order to find the oxidative effects of solid supports on the reaction, we also studied the reaction of acyloin with 1,2-diaminobenzene (Table 1, entry 8). The microwave-assisted reaction of acyloin with 1,2diaminobenzene in presence of $\mathrm{MnO}_{2}$ as catalyst has recently been reported. ${ }^{23}$ The reaction was supposed to be carried out via a tandem oxidation process of acyloin to the corresponding 1,2-dicarbonyl.

The effects of the solid supports on the reaction yield of $\mathbf{1 a}$ are quite evident. The lower yield of acyloin compared to benzil is due to a further oxidation of acyloin to highly reactive 1,2-dicarbonyl intermediates followed by condensation with 1,2-diamines. While all supports have positive effect on the reaction of benzil and give improved yields, some of them show negative effect on the reaction of acyloin. Therefore, all solid supports, except basic alumina and molecular sieves, should have oxidative behavior in order to convert acyloin to quinoxalines in a one-pot procedure.

Although the effect of K10 Montmorillonite on the synthesis of quinoxalines under microwave irradiation has been recently reported, ${ }^{24}$ acidic alumina shows the highest efficiency for both benzil and acyloin (Table 1, entry 1). In this regard, the acidic alumina was applied for the synthesis of products $\mathbf{1 a - h}$ depicted in Table 2 .

As shown in Table 2, a remarkable improved yield of products 1a-h was observed when the solvent-free reaction mixture was irradiated on acidic alumina in a microwave oven.

\section{Application of a polar paste of the reactants}

In the second series of experiments, a paste of the reactants was exposed under microwave irradiation. A very small amount of DMSO or diglyme $(0.2 \mathrm{~mL})$ is added to substrates to make a paste. This polar paste system has high heating potential with low vapor pressure; thereby the enhancement of its suitability was studied in order to find the heating effect on the reaction.

With respect to microwave irradiation, it is important to indicate that a total reaction time of 3 min corresponds, in fact, to 9 or 12 cycles of 15-20 seconds, with cooling periods (30 seconds) between them, which are used to control temperature about $120^{\circ} \mathrm{C}$ and also to monitor the reaction progress by TLC, so that the yields indicated in Table 3 were those optimized. The pure products precipitate out of the reaction medium on adding water in a highly improved yield.

We have shown earlier that succinic acid and different types of $o$-phenylenediamine could be efficiently condensed under microwave heating. ${ }^{25}$

Table 1. Preparation of 1a: Clay-catalyzed condensation of benzene-1,2-diamine with both benzil and acyloin under microwave irradiation for 3 minutes ${ }^{a}$

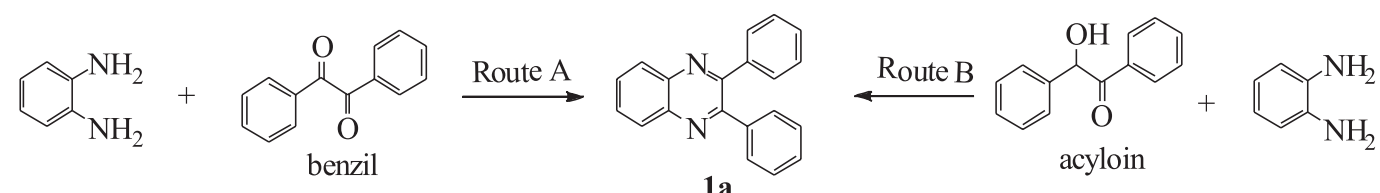

1a

\begin{tabular}{lccc}
\hline Entry & Solid Support & Yield $/(\%)^{\mathrm{b}}$ & ${\text { Yield } /(\%)^{\mathrm{c}}}^{\mathrm{b}}$ \\
\hline 1 & Acidic Alumina & 96 & 82 \\
2 & Neutral Alumina & 95 & 81 \\
3 & Basic Alumina & 91 & 18 \\
4 & Molecular Sieves (4 A) & 95 & 36 \\
5 & Silica Gel & 81 & 75 \\
6 & HY- Zeolite & 93 & 79 \\
7 & Montmorillonite K10 & 90 & 74 \\
8 & None & 65 & 51 \\
\hline
\end{tabular}

${ }^{\mathrm{a}}$ The yield of product is based on GC analysis. ${ }^{\mathrm{b}}$ Solvent-free condition: benzene-1,2-diamine $(1.1 \mathrm{mmol})+$ benzil (1 mmol). ${ }^{\mathrm{c}}$ Solvent-free condition: benzene-1,2-diamine $(1.1 \mathrm{mmol})+$ acyloin $(1 \mathrm{mmol})$. 
Table 2. Acidic alumina-catalyzed condensation between various diamines and $\alpha$-dicarbonyls under microwave irradiation

\begin{tabular}{|c|c|c|c|}
\hline$\gamma \mathrm{N}$ & $\mathrm{Y}=\mathrm{Ph}, \mathrm{H}$ & ina & \\
\hline Diamine & $\alpha$-dicarbonyl & Product & $\operatorname{Yield} /(\%)^{\mathrm{a}},[\%]^{\mathrm{b}}$ \\
\hline benzene-1,2-diamine & benzil & 1a & (96), [85] \\
\hline 4-methylbenzene-1,2-diamine & benzil & $1 \mathrm{~b}$ & $(96),[86]$ \\
\hline 4,5-dimethylbenzene-1,2-diamine & benzil & $1 \mathrm{c}$ & (95), [86] \\
\hline 4-nitrobenzene-1,2-diamine & benzil & 1d & $(90),[80]$ \\
\hline cyclohexane-1,2-diamine & benzil & 1e & $(86),[80]$ \\
\hline pyridine-2,3-diamine & benzil & 1f & $(92),[83]$ \\
\hline ethylene-1,2-diamine & benzil & $1 \mathrm{~g}$ & (90), [81] \\
\hline benzene-1,2-diamine & phenylglyoxal monohydrate & $1 \mathrm{~h}$ & (91), [81] \\
\hline
\end{tabular}

${ }^{a}$ The yield of product is based on GC analysis, 'Isolated yield.

In order to study the heating effect on the synthesis of products, we have first studied the effect of microwave energy on the reaction rate of benzil under solvent-free condition and found the effectiveness of microwaves on the reaction (60-70\%). Then, the combination of either solid supports or polar paste system with microwave was examined. We applied acidic alumina as a green catalyst in microwave chemistry which its efficiency was clearly proved (Table 2, 80-86\%). Moreover, a polar paste system with low vapour pressure gave the best yield of products (Table 3, 90-97\%). Although both methods implemented in this study have been designed to circumvent additional purification steps, the latter is cleaner with an easier work-up.

\section{Conclusions}

In summary, two benign, simple, solvent-free and versatile routes to quinoxalines $\mathbf{1}$ in high yield have been demonstrated. In order to investigate the microwave energy transfer system both mineral supports and a polar paste system were surveyed. We have found that acidic alumina is a good catalyst in a new, solvent-free, microwaveassisted method for the products synthesis. Acidic alumina also plays an important role in the tandem oxidation of acyloin to give products in a one-pot procedure.

On the other hand, the most significant result remains on using a polar paste system. The excellent product yields

Table 3. Polar paste-catalyzed condensation between various diamines and $\alpha$-dicarbonyls under microwave irradiation

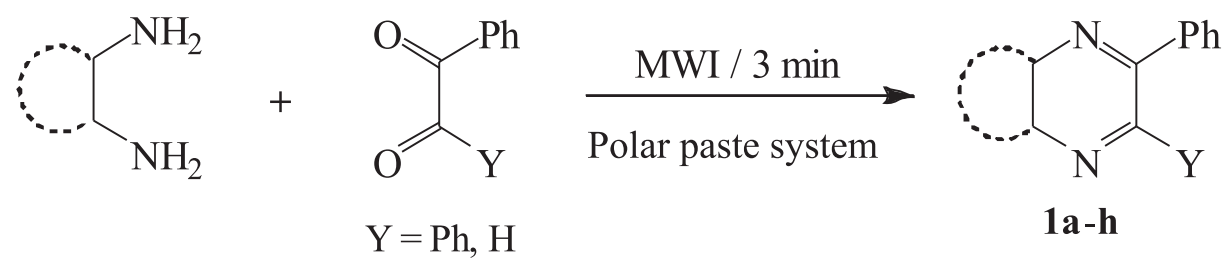

\begin{tabular}{|c|c|c|c|c|c|}
\hline Diamine & $\alpha$-dicarbonyl & Product & $\mathrm{DMSO} /(\%)^{\mathrm{a}}$ & Diglyme $/(\%)^{\mathrm{a}}$ & $\mathrm{mp} /\left({ }^{\circ} \mathrm{C}\right)$ \\
\hline benzene-1,2-diamine & benzil & $\mathbf{1 a}$ & 95 & 96 & 124 \\
\hline 4-methylbenzene-1,2-diamine & benzil & $\mathbf{1 b}$ & 96 & 96 & 109 \\
\hline 4,5-dimethylbenzene-1,2 diamine & benzil & $1 \mathrm{c}$ & 97 & 97 & 172 \\
\hline 4-nitrobenzene-1,2-diamine & benzil & 1d & 90 & 91 & 183 \\
\hline cyclohexane-1,2-diamine & benzil & $1 \mathrm{e}$ & 90 & 91 & 167 \\
\hline pyridine-2,3-diamine & benzil & 1f & 91 & 93 & 135 \\
\hline ethylene-1,2-diamine & benzil & $1 \mathrm{~g}$ & 93 & 94 & 163 \\
\hline benzene-1,2-diamine & phenylglyoxal monohydrate & 1h & 93 & 94 & 78 \\
\hline
\end{tabular}

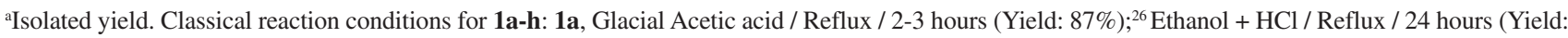
$87 \%) ;{ }^{27}$ Iodine $/ \mathrm{CH}_{3} \mathrm{CN} /$ Room Temperature (Yield: $98 \%$ ); ${ }^{10} \mathbf{1 b}$, ball-mill $/ 100{ }^{\circ} \mathrm{C} /$ vacuum $/ 15$ min (Yield: $\left.100 \%\right) ;{ }^{28} 100{ }^{\circ} \mathrm{C}$ (Yield: $\left.68 \%\right) ;{ }^{29} \mathbf{1 c}, \mathrm{NaHSO}_{3}$, $\mathrm{Na}_{2} \mathrm{~S}_{2} \mathrm{O}_{5} / \mathrm{H}_{2} \mathrm{O} / 80^{\circ} \mathrm{C} / 10 \mathrm{~min}$ (Yield: $97 \%$ ); $;{ }^{30} \mathbf{1 d}$, ball-mill/160 ${ }^{\circ} \mathrm{C} /$ vacuum $/ 15 \mathrm{~min}$ (Yield: $100 \%$ ) $;{ }^{28} 160{ }^{\circ} \mathrm{C}$ (Yield: $57 \%$ ); ${ }^{31} \mathbf{1 e}$, benzene / $130{ }^{\circ} \mathrm{C} / 6$ hours (Yield: 49-57\%); $;^{32}$ 1f, Ethanol / Reflux / 30 min (Yield: 77\%); $;^{33}$ 1g, Isopropyl alcohol / Reflux / 45 hours (Yield: 75\%); ${ }^{26}$ 1h, Toluene / THF / Pd(OAc) / Reflux / 3 hours (Yield: 83\%); ${ }^{23}$ Activated $\mathrm{MnO}_{2} / \mathrm{CH}_{2} \mathrm{Cl}_{2} /$ Molecular sieves / Reflux / 90 min (Yield: $79 \%$ ). ${ }^{6}$ 
and simple washing with water and filtration in absence of organic solvent make this methodology as an alternative platform under the umbrella of environmentally greener and safer processes. In general, these approaches lead to a clean, efficient and economical technology (green chemistry); safety is largely increased, work-up is considerably simplified, cost is reduced.

The extension of this type of reaction is actually under progress.

\section{Experimental}

Melting points are determined on Büchi 530 and are uncorrected. For the known compounds, the characterization was made by melting point and ${ }^{1} \mathrm{H}$ NMR on Bruker-80 MHz spectrometer. ${ }^{1} \mathrm{H}$ and ${ }^{13} \mathrm{C}$ NMR spectra were recorded for new compounds on Bruker-500 $\mathrm{MHz}$ spectrometer. All NMR samples were run in $\mathrm{CDCl}_{3}$ and chemical shifts are expressed as ppm relative to internal $\mathrm{Me}_{4} \mathrm{Si}$. A GC-MS method for the analysis of mixtures was applied. A Fisons instruments gas chromatograph 8000 connected to a mass detector (Trio 1000) with $70 \mathrm{eV}$ was used. A $30 \mathrm{~m} \times 0.25 \mathrm{~mm}$ column packed with WCOT (Wall Coated Open Tubular) fused silica CP-sil 5CB-MS (from CHROMPAC) was employed. Column temperature was programmed from 80 to $270{ }^{\circ} \mathrm{C}$ at $10{ }^{\circ} \mathrm{C} \mathrm{min}^{-1}$. Injection was performed at $280{ }^{\circ} \mathrm{C}$. The carrier gas was helium and the inlet pressure was 10 psi.

Column chromatography was carried out with the use of Merck Art.7734 kieselgel 60, 70-230 mesh ASTM. Substrates are commercially available and used without further purification. A domestic microwave oven from National (model NN-6755 operating at $2450 \mathrm{MHz}, 900$ $\mathrm{W}$ power) was used for all syntheses. Based on ASTM microwave calibration F1317-98 (2002), the averaged real power of microwave oven was found to be $780 \mathrm{~W}$. The temperature of the reaction mixture was measured by a laser infrared thermometer (Allafrance 910.0500/IRVL) which its max output is $1 \mathrm{~mW}$ and wavelength is $670 \mathrm{~nm}$ with $1{ }^{\circ} \mathrm{C}$ resolution and $\pm 2{ }^{\circ} \mathrm{C}$ accuracy.

\section{General experimental procedure}

All of the solid supports have been activated and dried in microwave for 2 minutes. Moreover, it is essential to work in an open vessel to enable the water formed to escape from the reaction mixture.

Synthesis of 1 by microwave irradiation on acidic alumina

In a domestic microwave oven, a mixture of diamine (1.1 mmol) and $\alpha$-dicarbonyl ( $1 \mathrm{mmol}$ ) on acidic alumina
$(0.2 \mathrm{~g})$ in an open pyrex glass flask, was heated under 900 $\mathrm{W}$ power irradiation for 3 minutes. The mixture was boiled in aqueous ethanol and filtered to remove alumina. Recrystallization from $70 \%$ ethanol, in some cases methanol, afforded a pure product.

Synthesis of 1 by microwave irradiation on a polar paste system

$0.2 \mathrm{~mL}$ of DMSO was added to a mixture of diamine (1.1 mmol) and $\alpha$-dicarbonyl $(1 \mathrm{mmol})$ in an open pyrex glass flask and stirred for 2 minutes. The obtained paste was exposed to microwave irradiation at $900 \mathrm{~W}$ power for 3 minutes. The mixture was treated with water to dissolve the remaining amount of polar solvent. The precipitate was crystallized with hot aqueous ethanol. After cooling the filtrate, the resulted crystals were collected by filtration to afford products $\mathbf{1 a}-\mathbf{h}$.

\section{2,3-Diphenylquinoxaline (1a)}

White crystals $(\mathrm{EtOH}), \mathrm{mp} 124^{\circ} \mathrm{C}\left(124^{\circ} \mathrm{C}\right)^{26}(122-$ $\left.124^{\circ} \mathrm{C}\right)^{27}\left(126-127^{\circ} \mathrm{C}\right)^{10} ;{ }^{1} \mathrm{H}$ NMR $\left(500 \mathrm{MHz}, \mathrm{CDCl}_{3}\right): \delta$ $7.40(\mathrm{~m}, 6 \mathrm{H}), 7.58(\mathrm{~m}, 4 \mathrm{H}), 7.83(\mathrm{~m}, 2 \mathrm{H}), 8.23(\mathrm{~m}, 2 \mathrm{H})$; ${ }^{13} \mathrm{C}$ NMR (125 MHz, $\left.\mathrm{CDCl}_{3}\right): \delta 128.70$ (2C), 129.23, $129.65,130.28$ (2C), 130.37, 139.54, 141.68, 153.91; MS (EI), $m / z$ (rel. intensity\%) $282\left(\mathrm{M}^{+}, 100\right), 281$ (95), 179 (50), 140 (35), 103 (15), 76 (35).

\section{2,3-Diphenyl-6-methylquinoxaline (1b)}

White crystals $(\mathrm{EtOH}), \mathrm{mp} 109{ }^{\circ} \mathrm{C}\left(109-110{ }^{\circ} \mathrm{C}\right)^{28}$ $\left(11{ }^{\circ} \mathrm{C}\right)^{29} ;{ }^{1} \mathrm{H} \mathrm{NMR}\left(\mathrm{CDCl}_{3}\right): \delta 2.64(\mathrm{~s}, 3 \mathrm{H}), 7.35(\mathrm{~m}$, $6 \mathrm{H}), 7.54(\mathrm{~m}, 4 \mathrm{H}), 7.63(\mathrm{~d}, 1 \mathrm{H}), 8.03(\mathrm{~s}, 1 \mathrm{H}), 8.14(\mathrm{~d}$, $1 \mathrm{H}) ;{ }^{13} \mathrm{C} \mathrm{NMR}\left(\mathrm{CDCl}_{3}\right): \delta 22.01,127.69,128.31$ (4C), 128.52, 128.88, 128.98, 129.89 (2C), 129.94 (2C), 132.68, 138.55, 138.68, 139.48, 140.81, 141.02, 152.47, 153.07; MS (EI), m/z (rel. intensity\%) $295\left(\mathrm{M}^{+}, 70\right), 192$ (40), 165 (55), 103 (50), 89 (100), 77 (35).

\section{6,7-Dimethyl-2,3-diphenylquinoxaline (1c)}

White crystals (EtOH), mp $172{ }^{\circ} \mathrm{C}(-)^{30} ;{ }^{1} \mathrm{H}$ NMR $\left(\mathrm{CDCl}_{3}\right): \delta 2.56(\mathrm{~s}, 6 \mathrm{H}), 7.38(\mathrm{~m}, 6 \mathrm{H}), 7.53(\mathrm{~m}, 4 \mathrm{H}), 8.11$ $(\mathrm{s}, 2 \mathrm{H}) ;{ }^{13} \mathrm{C} \mathrm{NMR}\left(\mathrm{CDCl}_{3}\right): \delta 20.52,127.94,128.26(2 \mathrm{C})$, 128.77, 129.91 (2C), 138.82, 139.88, 141.01, 152.30; MS (EI), $m / z$ (rel. intensity\%) $310\left(\mathrm{M}^{+}, 100\right), 206$ (20), 155 (45), 147 (30), 103 (40), 77 (25).

\section{6-Nitro-2,3-diphenylquinoxaline (1d)}

White crystals $(\mathrm{EtOH}), \mathrm{mp} 185^{\circ} \mathrm{C}\left(186.5-187.5^{\circ} \mathrm{C}\right)^{28}$ $\left(187.5-187.9^{\circ} \mathrm{C}\right)^{31} ;{ }^{1} \mathrm{H}$ NMR $\left(\mathrm{CDCl}_{3}\right): \delta 7.42(\mathrm{~m}, 6 \mathrm{H})$, $7.58(\mathrm{~m}, 4 \mathrm{H}), 8.32(\mathrm{~d}, 1 \mathrm{H}), 8.57(\mathrm{dd}, 1 \mathrm{H}), 9.10(\mathrm{~d}, 1 \mathrm{H})$; ${ }^{13} \mathrm{C} \mathrm{NMR}\left(\mathrm{CDCl}_{3}\right): \delta 123.33,125.65,128.49$ (4C), 129.67, 129.80, 129.83 (2C), 129.91 (2C), 130.78, 138.00, 138.07, 
139.97, 143.59, 147.86, 155.71, 156.34; MS (EI), $\mathrm{m} / z$ (rel. intensity\%) 327 ( $\left.\mathrm{M}^{+}, 100\right), 224$ (50), 103 (60), 77 (30).

\section{trans-4a,5,6,7,8,8a-Hexahydro-2,3-diphenylquinoxaline} (1e)

Yellow crystals $(\mathrm{EtOH}), \mathrm{mp}: 167^{\circ} \mathrm{C}\left(168-172{ }^{\circ} \mathrm{C}\right)^{32}$; ${ }^{1} \mathrm{H}$ NMR (500 MHz, $\left.\mathrm{CDCl}_{3}\right): \delta 1.48(\mathrm{~d}, 2 \mathrm{H}), 1.68(\mathrm{~d}$, $2 \mathrm{H}), 1.95$ (d, 2H), $2.56(\mathrm{~d}, 2 \mathrm{H}), 2.90(\mathrm{dd}, 2 \mathrm{H}) ; 7.26-7.29$ (m, 4H), 7.31-7.35 (dd, 2H), 7.41-7.45 (d, 4H); ${ }^{13} \mathrm{C}$ NMR $\left(125 \mathrm{MHz} \mathrm{CDCl}_{3}\right): \delta 25.88,33.96,59.99,128.46$ (2C), 128.54 (2C), 129.87, 138.26, 160.09; MS (EI), $m / z$ (rel. intensity\%) $288\left(\mathrm{M}^{+}, 20\right), 165$ (15), 104 (100), 67 (45), 54 (30).

\section{2,3-Diphenylpyrido[2,3-b]pyrazine (1f)}

Yellow crystals $(\mathrm{MeOH}), \mathrm{mp} 138{ }^{\circ} \mathrm{C}\left(141-142{ }^{\circ} \mathrm{C}\right)^{33}$; ${ }^{1} \mathrm{H}$ NMR (500 MHz, $\left.\mathrm{CDCl}_{3}\right): \delta 7.34-7.45(\mathrm{~m}, 5 \mathrm{H}), 7.59$ $(\mathrm{d}, 2 \mathrm{H}), 7.66(\mathrm{~d}, 2 \mathrm{H}), 7.73-7.76(\mathrm{dd}, 2 \mathrm{H}), 8.54-8.56(\mathrm{dd}$, $1 \mathrm{H}), 9.20(\mathrm{~d}, 1 \mathrm{H}) ;{ }^{13} \mathrm{C} \mathrm{NMR}\left(125 \mathrm{MHz}, \mathrm{CDCl}_{3}\right): \delta 125.64$, 128.58 (2C), 128.83 (2C), 129.72, 129.86, 130.23 (2C), 130.67, 136.60, 138.51 (2C), 138.94, 150.27, 154.49 (2C), 155.15, 156.75.; MS (EI), $\mathrm{m} / z$ (rel. intensity\%) $283\left(\mathrm{M}^{+}\right.$, 70), 179 (85), 103 (100), 77 (70).

\section{2,3-Dihydro-5,6-diphenylpyrazine (1g)}

White crystals $(\mathrm{MeOH}), \mathrm{mp} 163^{\circ} \mathrm{C}\left(166-167{ }^{\circ} \mathrm{C}\right) ;{ }^{26}$ ${ }^{1} \mathrm{H}$ NMR (500 MHz, $\mathrm{CDCl}_{3}$ ): $\delta 3.74(\mathrm{~s}, 4 \mathrm{H}), 7.27-7.30$ (m, 4H), 7.34 (d, 2H), 7.44 (d, 4H); ${ }^{13} \mathrm{C}$ NMR (125 MHz, $\left.\mathrm{CDCl}_{3}\right): \delta 46.26,128.33$ (2C), 128.54 (2C), 130.05, 138.21, 160.73; MS (EI), m/z (rel. intensity\%) $234\left(\mathrm{M}^{+}\right.$, 35), 131 (35), 103 (100), 77 (40), 51 (30).

\section{2-Phenylquinoxaline (1h)}

White crystals $(\mathrm{EtOH}), \mathrm{mp} 78{ }^{\circ} \mathrm{C}\left(79-80{ }^{\circ} \mathrm{C}\right)^{6,23} ;{ }^{1} \mathrm{H}$ NMR $\left(\mathrm{CDCl}_{3}\right): \delta 7.59(\mathrm{~m}, 3 \mathrm{H}), 7.80(\mathrm{~m}, 2 \mathrm{H}), 8.20(\mathrm{~m}$, $4 \mathrm{H}), 9.35(\mathrm{~s}, 1 \mathrm{H}) ;{ }^{13} \mathrm{C} \mathrm{NMR}\left(\mathrm{CDCl}_{3}\right): \delta 127.61$ (2C), $128.84,129.23$ (2C), 129.60, 129.82, 130.37, 130.55, 136.55, 141.05, 142.33, 142.95, 151.92; MS (EI), $m / z$ (rel. intensity\%) $206\left(\mathrm{M}^{+}, 100\right), 179$ (70), 152 (30), 103 (50), 77 (45), 50 (60).

\section{Supplementary Information}

Supplementary data are available free of charge at http://jbcs.sbq.org.br, as PDF file.

\section{References}

1. Hassan, S. Y.; Khattab, S. N.; Bekhit, A. A.; Amer, A.; Bioorg. Med. Chem. Lett. 2006, 16, 1753; Perumal, R. V.; Mahesh, R.; Bioorg. Med. Chem. Lett. 2006, 16, 2769; Zhao, Z.; Leister, W.
H.; Robinson, R. G.; Barnett, S. F.; Defeo-Jones, D.; Jones, R. E.; Hartman, G. D.; Huff, J. R.; Huber, H. E.; Duggan, M. E.; Lindsley, C. W.; Bioorg. Med. Chem. Lett. 2005, 15, 905; Arthur, G.; Elor, K. B.; Robert, G. S.; Guo, Z. Z.; Richard, J. P.; Stanley, D.; John, R. K.; Sean, T.; J. Med. Chem. 2005, 48, 744; Andres, J.; Belen, Z.; Ibnacio, A.; Antonio, M.; J. Med. Chem. 2005, 48, 2019; Lainne, E. S.; William, J. S.; Robert, C. R.; J. Med. Chem. 2002, 45, 5604; Seitz, L. E.; Suling, W. J.; Reynolds, R. C.; J. Med. Chem. 2002, 45, 5604; Ali, M. M.; Ismail, M. M. F.; EIGabby, M. S. A.; Zahran, M. A.; Ammar, T. A.; Molecules 2000, 5, 864; Sakata, G.; Makino, K.; Kurasawa, Y.; Heterocycles 1998, 27, 2481; Gazit, A.; App, H.; McMahon, G.; Chen, J.; Levitzki, A.; Bohmer, F. D.; J. Med. Chem. 1996, 39, 2170; Ahmad, A. R.; Mehta, L. K.; Parrick, J.; Tetrahedron 1995, 51, 12899; Matsuoka, M.; Iwamoto, I.; Furukawa, N.; Kitao T.; J. Heterocycl. Chem. 1992, 29, 439; Sarges, R.; Howard, H. R.; Browne, R. C.; Label, L. A.; Seymour, P. A.; J. Med. Chem. 1990, 33, 2240;

2. Bailly, C.; Echepare, S.; Gago, F.; Waring, M.; Anti-Cancer Drug Des. 1999, 15, 291; Dell, A.; William, D. H.; Morris, H. R.; Smith, G. A.; Feeney, J.; Roberts, G. C. K.; J. Am. Chem. Soc. 1975, 97, 2497; Sato, S.; Shiratori, O.; Katagiri, K.; J. Antibiot. 1967, 20, 270.

3. Gobec, S.; Urleb, U. In Science of Synthesis, Houben-Weyl Methods of Molecular Transformations, Yamamoto, Y. ed.; Georg Thieme Verlag- Stuttgart: New York, 2004, category 2, vol. 16, pp. $845-911$.

4. Kim, S. Y.; Park, K. H.; Chung, Y. K.; Chem. Commun. 2005, 1321.

5. Antoniotti, S.; Dunach, E.; Tetrahedron Lett. 2002, 43, 3971.

6. Raw, S. A.; Wilfred, C. D.; Taylor, R. J. K.; Chem. Commun. 2003, 2286.

7. Sato, N. In Comprehensive Heterocyclic Chemistry II; Katritzky, A. R.; Rees, C. W.; Scrivon, E. F. V., eds.; Elsevier Science Ltd.: Oxford, 1996, vol. 6, pp. 233 - 278.

8. Brown, D. J. In Quinoxalines: SUPLEMENT II, The Chemistry of Heterocyclic Compounds; Taylor, E. C.; Wipf, P., eds.; John Wiley \& Sons: New Jersey, 2004.

9. Bhosale, R. S.; Sarda, S. R.; Ardhapure, S. S.; Jadhav, W. N.; Bhusare, S. R.; Pawar, R. P.; Tetrahedron Lett. 2005, 46, 7183.

10. More, S. V.; Sastry, M. N. V.; Wang, C-C.; Yao, C-F.; Tetrahedron Lett. 2005, 46, 6345.

11. Anastas, P. T.; Warner, J. C.; Green Chemistry, Theory and Practice, Oxford University Press: Oxford, UK, 1998.

12. Loupy, A.; C. R. Chimie 2004, 7, 103.

13. Villemin, D.; Martin, B.; Synth. Commun. 1995, 25, 2319.

14. Juncai, F.; Yang, L.; Qinghua, M.; Bin, L.; Synth. Commun. 1998, 28, 193.

15. Rostamizadeh, S.; Jafari, S.; Indian J. Heterocycl. Chem. 2001, 10, 303.

16. Zhao, Z.; Wisnoski, D. D.; Wolkenberg, S. E.; Leiser, W. H.; Wang, Y.; Lindsley, W.; Tetrahedron Lett. 2004, 45, 4873. 
17. Lidström, P.; Tierney, J.; Wathey, B.; Westman, J.; Tetrahedron 2001, 57, 9225.

18. Bougrin, K.; Loupy, A.; Soufiaoui, M.; J. Photochem. Photobiol., C 2005, 6, 139.

19. Nooshabadi, M.; Aghapoor, K.; Darabi, H. R.; Mojtahedi, M. M.; Tetrahedron Lett. 1999, 40, 7549; Darabi, H. R.; Aghapoor, K.; Tabar-Heydar, K.; Phosphorus, Sulfur Silicon Relat. Elem. 2002, 177, 1189; Aghapoor, K.; Darabi, H. R.; Nooshabadi, M.; Tabar-Heydar, K.; Phosphorus, Sulfur Silicon Relat. Elem. 2002, 177, 1183; Aghapoor, K.; Darabi, H. R.; Tabar-Heydar, K.; Nakhshab, L.; Sulfur Lett. 2002, 25, 259; Darabi, H. R.; Aghapoor, K.; Nakhshab, L.; Z. Naturforsch., b: Chem. Sci. 2004, 59, 601; Darabi, H. R.; Aghapoor, K.; Tajbakhsh, M.; Tetrahedron Lett. 2004, 45, 4167; Darabi, H. R.; Aghapoor, K.; Tabar-Heydar, K.; Monatsh. Chem. 2004, 135, 79.

20. Gothelf, K. V; Jorgensen, K. A.; Chem. Rev. 1998, 98, 863.

21. Gutiérrez, A.; Loupy, A.; Bram, G.; Ruiz-Hitzky, E.; Tetrahedron Lett. 1989, 30, 945; Loupy, A.; Petit, A.; Hamelin, J.; Texier-Boullet, F.; Jacquault, P.; Mathé, D.; Synthesis 1998, 1213 and references therein; Varma, R. S.; Green Chem. 1999, 1, 43; Varma, R. S.; Tetrahedron 2002, 58, 1235.

22. McKillop, A.; Young, D. W.; Synthesis 1979, 481; Laszlo, P.; Acc. Chem. Res. 1986, 19, 121; Kabalka, G. W.; Ragni, R. M.;
Tetrahedron 1997, 53, 7999; Loupy, A.; Top. Curr. Chem. 1999, 206, 153; Kidwai, M.; Pure Appl. Chem. 2001, 73, 147.

23. Robinson, R. S.; Taylor, R. J. K.; Synlett 2005, 1003.

24. Azizian, J.; Karimi, A. R.; Kazemizadeh, Z.; Mohammadi, A. A.; Mohammadizadeh, M. R.; Tetrahedron Lett. 2005, 46, 6155.

25. Aghapoor, K.; Darabi, H. R.; Mohsenzadeh, F.; Z. Naturforsch., b: Chem. Sci. 2005, 60, 901.

26. Ohta, A.; Masano, S.; Iwakura, S.; Tamura, A.; Kurihara, T.; J. Heterocycl. Chem. 1982, 19, 465.

27. Yoram Cohen, Y.; Meyer, A. Y.; Rabinovitz, M.; J. Am. Chem. Soc. 1986, 108, 7039.

28. Kappe, G.; Naimi-Jamal, M. R.; Eur. J. Org. Chem. 2002, 1368.

29. Siegrist, A. E.; Helv. Chim. Acta 1967, 50, 906.

30. While molecule is known, but no mp was found in the literature; Liu, J-H; Wu, A-T.; Huang, M-H.; Wu, C-W.; Chung, W-S.; J. Org. Chem. 2000, 65, 3395.

31. Mallory, F. B.; Wood, C. S.; Hurwitz, B. M.; J. Org. Chem. 1964, 29, 2605.

32. Smith, A. I.; US pat. 3,163,675 1964.

33. Kaye, I. A.; J. Med. Chem. 1964, 7, 240.

Received: April 25, 2006

Web Release Date: February 15, 2007 